\title{
Structural Role of Cerium Oxide in Lead Silicate Glasses and Glass Ceramics
}

\author{
Gomaa El-Damrawi ${ }^{*}$, Amal Behairy² \\ ${ }^{1}$ Physics Department, Faculty of Science, Mansoura University, Mansoura, Egypt \\ ${ }^{2}$ The High Institute of Engineering and Technology, New Damietta, Damietta, Egypt \\ Email: ^gomaaeldamrawi@gmail.com
}

How to cite this paper: El-Damrawi, G. and Behairy, A. (2018) Structural Role of Cerium Oxide in Lead Silicate Glasses and Glass Ceramics. Journal of Minerals and Materials Characterization and Engineering, 6, 438-447.

https://doi.org/10.4236/jmmce.2018.63031

Received: April 16, 2018

Accepted: May 27, 2018

Published: May 30, 2018

Copyright (๑) 2018 by authors and Scientific Research Publishing Inc. This work is licensed under the Creative Commons Attribution-NonCommercial International License (CC BY-NC 4.0). http://creativecommons.org/licenses/by-nc/4.0/

\begin{abstract}
Silicate glasses and glass ceramics in the system $\mathrm{CeO}_{2}-\mathrm{PbO}-\mathrm{SiO}_{2}$ have been studied as a function of the structure factors $\mathrm{R}$ and $\mathrm{K}$. The latter two factors are defined as: $\mathrm{R}=\left(\mathrm{CeO}_{2}+\mathrm{PbO}\right) / \mathrm{SiO}_{2}$ and $\mathrm{K}=\left(\mathrm{SiO}_{2} / \mathrm{CeO}_{2}\right)$ molar ratios. In this glass, $\mathrm{PbO}$ is fixed at $50 \mathrm{~mol} \%$ and $\mathrm{CeO}_{2}$ increases at the expense of $\mathrm{SiO}_{2}$. NMR investigations have revealed that increasing $R$ which is accompanied with decreasing $\mathrm{K}$ leads to reasonable decrease in the shielding of silicon atoms. The chemical shift $(\delta)$ showed an increasing behavior due to increasing non-bridging oxygen atoms (NBO) in silicate network. It is evidenced that $\mathrm{NBO}$ in cerium free glass is much lower than that of glasses containing $\mathrm{CeO}_{2}$. Increasing $\mathrm{R}$ is clearly leading to higher chemical shift and higher NBO. This reflects that $\mathrm{CeO}_{2}$ has an effective structural role, since it would be consumed in all cases as an intermediate oxide. The main portions from $\mathrm{CeO}_{2}$ and $\mathrm{PbO}$ inter as glass modifiers which are consumed to form NBO atoms. A limited portion of $\mathrm{CeO}_{2}$ acts as glass former which consumed to form tetrahedral cerium containing $\mathrm{NBO}$ due to modification by $\mathrm{PbO}$ as a modifier oxide. Increasing $\mathrm{R}=\left[\left(\mathrm{CeO}_{2}+\mathrm{PbO}\right) / \mathrm{SiO}_{2}\right]$ from 1 to 2.34 leads to a frequent increase of NBO in the average glass network. FTIR spectroscopy of the glasses showed a clear shift of the main absorbance peak toward the low wavenumber with increasing $\mathrm{R}$ which confirms the increasing silicate units containing NBO atoms. XRD of the investigated materials revealed the presence of some nanostructures from cerium silicate crystalline phases. Formation of separated phases containing micro clusters is found to depend on NBO concentration, since NBO can facilitate process of phase separation. Majority of modifier are consumed to form $\mathrm{NBO}$ in the glass network and the rest are aggregated or separated to form silicate phase riches with cerium cations. In such case, some of silicon atoms are electrically compensated with both $\mathrm{Pb}$ and Ce cations.
\end{abstract}

\section{Keywords}

Cerium in Glasses, Crystalline Clusters, NMR Feature, Glass Ceramics 


\section{Introduction}

Glass ceramics containing $\mathrm{PbO}$ are useful to be studied because of their importance in several fields of applications [1] [2] [3] [4] [5]. PbO can easily resist devitrification process and enhances durability of the glasses. Recently, the continuous progress of the materials containing cerium and lead oxide has been requiring immediate attention in viewpoint of both academic [6] [7] and bio-applications [8] [9] [10] [11]. Structural role of $\mathrm{PbO}$ and $\mathrm{CeO}_{2}$ as network intermediates is documented in several types of glasses [3] [4] [5]. This dual role is depending on their content, glass composition and the type of glass. $\mathrm{PbO}$ can modify silicate network similar to alkali oxide particularly at low concentration [12] [13]. In such situation, the modifiers are consumed to form silicate units containing NBO atoms [12] [13] [14]. In glasses enriched with lead, $\mathrm{PbO}_{4}$ species would be formed and directly affects the glass structure through forming $\mathrm{Pb}-\mathrm{O}-\mathrm{Si}$ bonds [5] [13].

Structure of cerium borate and borosilicate glasses has been recently investigated via FTIR and NMR spectroscopy [6] [7] [15] [16] [17]. The obtained results have proved that cerium ions have a role of a network intermediate. Although several investigations have been done to characterize micro-structure of lead silicate glasses, the role of $\mathrm{PbO}$ and $\mathrm{CeO}_{2}$ in studied silicate glass ceramics has not been fully explored. Our aim, in this study is to offer more information on the short range structure of cerium lead silicate glass ceramics in a wide range of composition. In particular, we focus on the short range ordered structure around the $\mathrm{Si}$ atoms via ${ }^{29} \mathrm{Si}$ NMR techniques. In addition, the role of cerium ions as an agent for phase separation and crystallization has also to be studied. In this regard, glasses are investigated with SEM, FTIR, XRD spectroscopies and the obtained data is compared with that of base glass, free from $\mathrm{CeO}_{2}$.

\section{Experimental}

Glass samples containing different concentrations from $\mathrm{CeO}_{2}, \mathrm{PbO}$ and $\mathrm{SiO}_{2}$ have been prepared by mixing the desired components in silica crucibles. The crucible and its content was transferred into an electric furnace and the temperature is raised gradually to reach the limit suitable for melting. The melting temperature is ranged between $1350^{\circ} \mathrm{C}-1450^{\circ} \mathrm{C}$, depending on the material composition. The melt was swirled severally to ensure homogeneity and to get bubble free matrix. Finally, the melt was poured between two stainless steel plates. The obtained samples are transferred to another furnace and annealed at $350^{\circ} \mathrm{C}$ to reduce internal stress. The samples are obtained in disc like shape of 2 $\mathrm{mm}$ thickness and $5 \mathrm{~mm}$ radius.

\section{1. ${ }^{29}$ Si NMR Measurements}

Fine powdered samples of different compositions have been investigated by using JEOL GSX-500 high-resolution solid state MAS NMR spectrometer of magnetic field of $11.74 \mathrm{~T}$ (Mansoura University-EGYPT). Spectra of silicon nuclei 
were recorded at a frequency of $99.3 \mathrm{MHz}$. A spinning rate of $7 \mathrm{kHz}$ has been applied by using zirconia sample holder. An electric Pulse of $2.62 \mu$ s length and of $30 \mathrm{~s}$ recycle delay are used. Several scans $(10,000-12,000)$ were acquired to get high resolution NMR spectra.

\subsection{X-Ray Diffraction Method}

XRD measurements were undertaken using a Bruker D5005 diffractmeter, at 40 $\mathrm{kV}-30 \mathrm{~mA}$ power. Scans were taken between $10^{\circ}-70^{\circ}$ with $0.04^{\circ}$ increments, 15 - 30 seconds/increment.

\subsection{Infrared Spectra (IR)}

The FTIR absorption spectra were obtained, by $\mathrm{KBr}$ pellets technique, at room temperature in the range $400-4000 \mathrm{~cm}^{-1}$ using Mattson 5000 FTIR spectrometer with a spectral resolution of $2 \mathrm{~cm}^{-1}$. The glass powder of $0.02 \mathrm{~g}$ was mixed with a $0.2 \mathrm{~g}$ of $\mathrm{KBr}$ and pressed to form a thin disc. At least three samples of each glass were analyzed. The spectrum of each sample is obtained due to collected 20 scans. The obtained spectrum was normalized to the spectrum of blank $\mathrm{KBr}$ pellet; i.e. a pure $\mathrm{KBr}$ spectrum was subtracted from each glass spectrum. In addition, the spectra were corrected to the background and dark currents using two-point baseline correction. Then the spectra were normalized by making the absorption of each spectrum varies between 0 and 1 arbitrary unit. In addition such normalization is necessary to eliminate the concentration effect of the powder sample in the $\mathrm{KBr}$ disc.

\section{Results and Discussion}

NMR spectra of glasses having different $R$ values (1, 1.2. 1.86 and 2.34) are shown in Figures 1(a)-(d). As shown from this figure, there is a remarkable shift in center of the main peak position of ${ }^{29} \mathrm{Si}$ NMR spectra with increasing $\mathrm{R}$, i.e. increasing $\mathrm{CeO}_{2}$ concentrations. The NMR resonance peak centered at -87.3 $\mathrm{ppm}$ in cerium free glass (spectrum a) is shifted clearly toward much higher value $(-75.4 \mathrm{ppm})$ in glass of $20 \mathrm{~mol} \% \mathrm{CeO}_{2}(\mathrm{R}=2.34)$. Increasing chemical shift of the silicate nuclei with increasing $\left(\mathrm{PbO}+\mathrm{CeO}_{2}\right)$ concentration is attributed to the modification role of both cerium and lead oxides. In addition, decreasing of $\mathrm{SiO}_{2}$ concentration as a result of increasing $\mathrm{CeO}_{2}$ and decreasing $\mathrm{K}$ will result in increasing $\mathrm{NBO}$ per $\mathrm{SiO}_{2}$ groups.

In terms of $\mathrm{Q}^{\mathrm{n}}$ notation, $(\mathrm{Q}$ is silicon atom and $\mathrm{n}$ is the number of bridging bonds between $\mathrm{Si}$ and oxygen atoms), chemical shift value of base glass ( -87.3 $\mathrm{ppm}$ ) is attributed to mixture of $\mathrm{Q}^{3}$ and $\mathrm{Q}^{2}$ (silicate unit containing three and two bridging oxygen atoms as a major portion). In addition, little of $\mathrm{Q}^{2}[\mathrm{OPb}]$ configurations may also be present [18] [19]. The main NMR resonances centered at $-83.3,-77.8$, and $-75.4 \mathrm{ppm}$ in glasses of $\mathrm{R}=1.2,1.68$ and $2.34\left(\mathrm{CeO}_{2}=\right.$ 5,15 and $20 \mathrm{~mol} \% \mathrm{CeO}_{2}$ ) show that silicate network is frequently deshielded by the effect of increasing the modifier oxide concentration. In glass of $\mathrm{R}=1.2$ and 


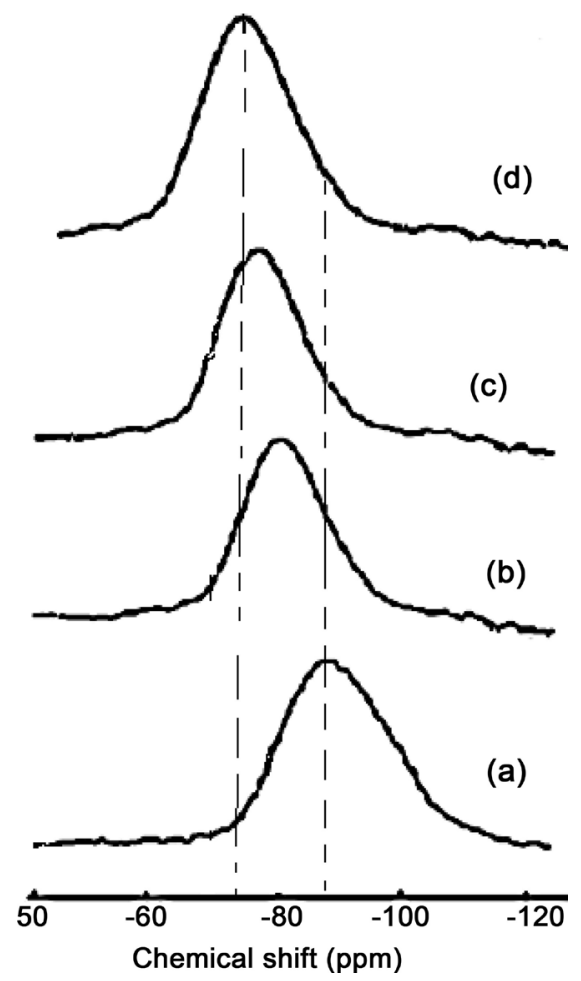

Figure 1. NMR spectra of silicon nuclei of cerium free, $\mathrm{R}=1$ (a) and of glasses containing 5 and 15 and $20 \mathrm{~mol} \% \mathrm{CeO}_{2}, \mathrm{R}=1.2,1.86$ and 2.34 ((b)-(d), respectively).

containing $5 \mathrm{~mol} \% \mathrm{CeO}_{2}, \mathrm{Q}^{2}$ species are the dominant. On the other hand, glasses containing 15 and $20 \mathrm{~mol} \% \mathrm{CeO}_{2}(\mathrm{R}=1.68$ and 2.34$)$ contain $\mathrm{Q}^{1}$ and $\mathrm{Q}^{0}$ species respectively. In addition few silicate units containing cerium oxide in the second coordination sphere are suggested to be present.

The concentration of different silicate units $\left(Q^{n}, n=0-4\right)$ could be quantitavely obtained by an integration process which is applied to all NMR spectra of silicon nuclei. Figure 2 is presented as an example for the deconvolution process. From spectral analysis, the corresponding percentage of $\mathrm{Q}^{1}=17 \%, \mathrm{Q}^{2}=$ $55 \%, \mathrm{Q}^{3}=20 \%$, and $\mathrm{Q}^{4}=8 \%$ characterize binary lead silicate glass are simply evidenced. On the other hand, the values of $\mathrm{Q}^{0}=29 \%, \mathrm{Q}^{1}=44 \%, \mathrm{Q}^{2}=23 \%, \mathrm{Q}^{3}=$ $4 \%$ and $\mathrm{Q}^{4}=0 \%$ are obtained values characterize ternary cerium lead silicate glass of $\mathrm{R}=1.86$. This leads one to confirm that the major portion from $\mathrm{CeO}_{2}$ and $\mathrm{PbO}$ can be introduced as glass modifier, since silicate units contain a mixture from $\mathrm{Q}^{1}$ and $\mathrm{Q}^{0}$ types are formed with higher concentration than that of $\mathrm{Q}^{2}$ and $\mathrm{Q}^{3}$ in glass free from $\mathrm{CeO}_{2}$. In such glass, some of $\mathrm{Q}^{\mathrm{n}}$ would contain $\mathrm{Ce}$ or $\mathrm{Pb}$ or both in the second coordination sphere of silicon. As a result, Si-O-Ce and $\mathrm{Ce}-\mathrm{O}-\mathrm{Pb}$ configurations are formed. These linkages are known to deshield the silicon nuclei in comparison with Si-O-Si linkages.

Figure 3 presents the change of the average isotropic chemical shift $(\delta)$ of ${ }^{29} \mathrm{Si}$ nuclei upon increasing R. It can be shown from this figure that $\delta$ increases (from -87.3 to $-75.4 \mathrm{ppm}$ ) with increasing $\mathrm{R}$ values i.e. $\mathrm{CeO}_{2}$ contents. This change leads to increasing NBO. Beside, some $\mathrm{Si}-\mathrm{O}-\mathrm{Ce}$ or $\mathrm{Si}-\mathrm{O}-\mathrm{Pb}$ are formed at expense 


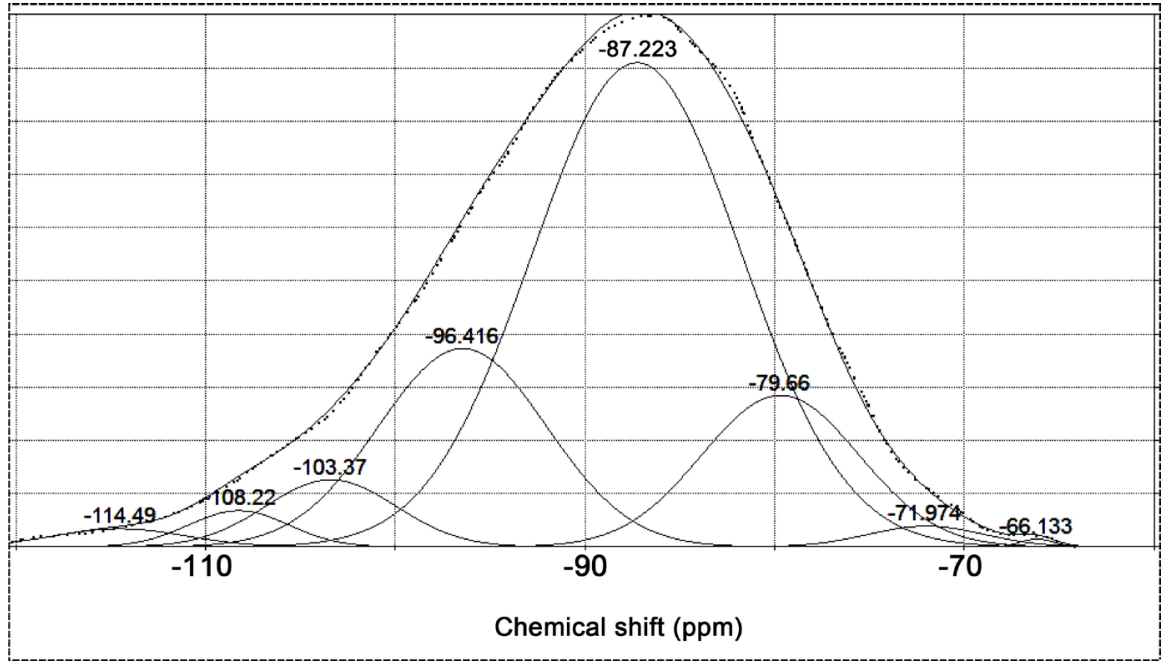

Figure 2. Separation of NMR spectrum of $50 \mathrm{PbO}-50 \mathrm{SiO}_{2}$ glass into different component bands.

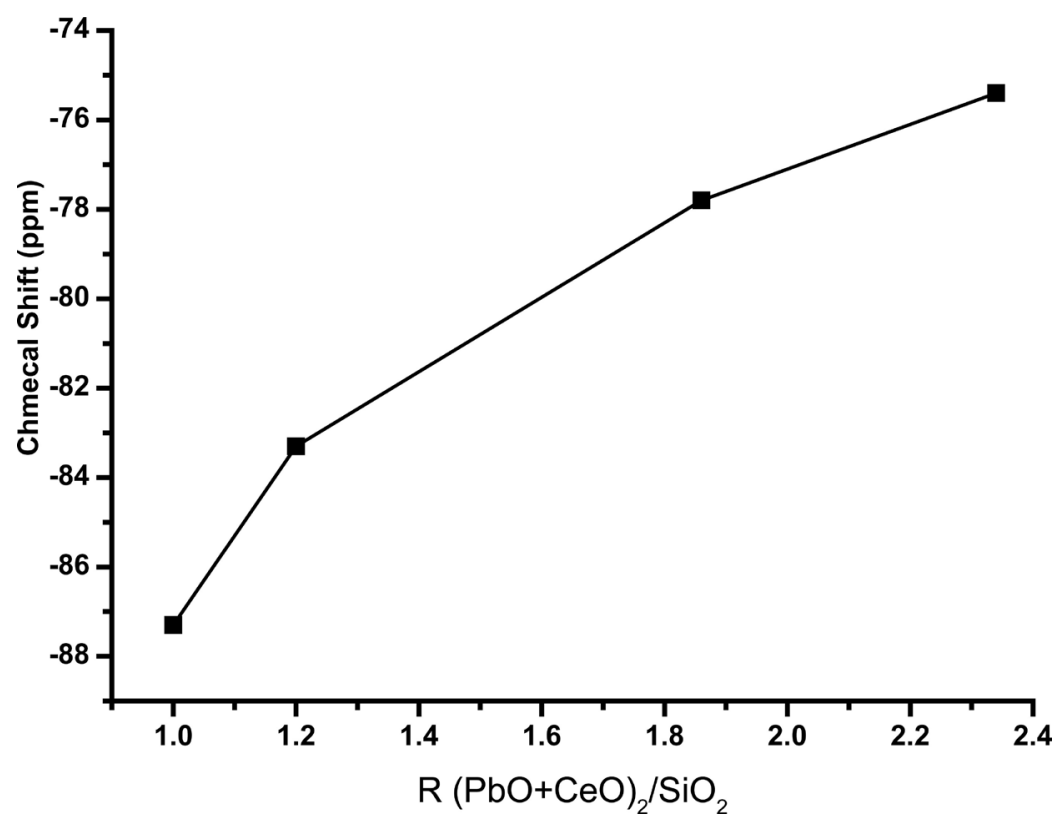

Figure 3. Relation between chemical shift of silicon nuclei and $\left(\mathrm{PbO}+\mathrm{CeO}_{2}\right) / \mathrm{SiO}_{2}$ molar ratio.

of the more stronger Si-O-Si bonds. This assures that cerium oxide inters the glass as an strong glass modifier. In addition, silicate units of the type $\mathrm{Ce}$ [2OSi] containing $\mathrm{NBO}$ atoms are formed. As a result $\mathrm{NBO}, \mathrm{Si}-\mathrm{O}-\mathrm{Ce}$ and $\mathrm{Pb}-\mathrm{O}-\mathrm{Si}$ bonds can deshield silicate units relative to stronger $\mathrm{Si}-\mathrm{O}-\mathrm{Si}$ bond in glasses of higher modification levels. Increasing deshielding upon increasing $\mathrm{CeO}_{2}$ concentration is the main reason of increasing chemical shift with increasing $\mathrm{CeO}_{2}$ concentration as represented in Figure 3.

To determine the structural role of $\mathrm{CeO}_{2}$ as an effective modifier, it is useful to compare FTIR spectra of cerium containing glasses with that of free $\mathrm{CeO}_{2}$. As an example, Figure 4 shows FTIR spectra of cerium free glass and for glass samples 


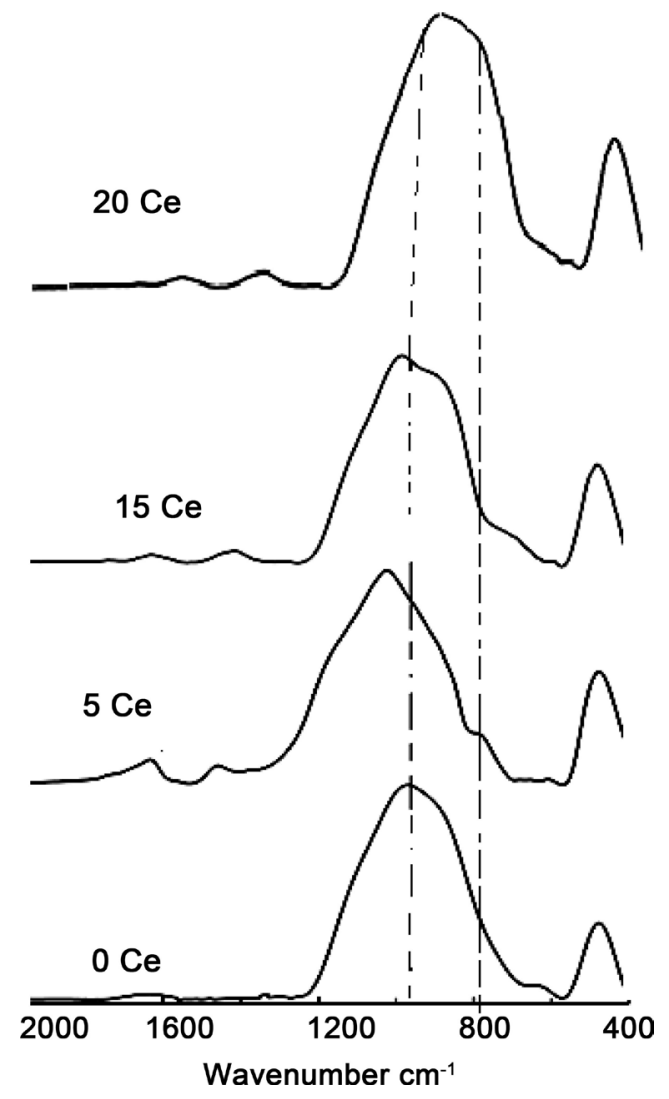

Figure 4. FTIR spectra of cerium free glass $(\mathrm{R}=1)$ and of that containing $5(\mathrm{R}=1.2)$ and $15(\mathrm{R}=1.86)$ and $20(\mathrm{R}=2.34) \mathrm{mol} \%$.

contains 5, 15 and $20 \mathrm{~mol} \% \mathrm{CeO}_{2}$ as an example. The main band at ca. $960 \mathrm{~cm}^{-1}$ in glass free from cerium oxide is shifted progressively towards $860 \mathrm{~cm}^{-1}$, since the activity of $\mathrm{Q}^{2}$ and $\mathrm{Q}^{1}$ species containing Ce linkages are present in glass containing 5 and $15 \mathrm{~mol} \%$. In addition, week envelope represents $\mathrm{Q}^{0}$ is appeared at about $770 \mathrm{~cm}^{-1}$ in the spectra of glass containing $20 \mathrm{~mol}^{2} \mathrm{CeO}_{2}$. These changes are clearly evidenced in glass of higher $\mathrm{CeO}_{2}$ oxide (15 and $20 \mathrm{~mol} \% \mathrm{CeO}_{2}$ ), see Figure 4. As is shown from this figure, band characterizes $\mathrm{Q}^{0}$ (at $770 \mathrm{~cm}^{-1}$ ) [20] [21] [22] [23] is simply resolved which confirms that loos silicate units would be formed in high $\mathrm{CeO}_{2}$ to $\mathrm{SiO}_{2}$ molar ratio.

The nature of XRD pattern is known to depend upon the content of NBO in the main glass forming units such as $\left[\mathrm{Q}^{\mathrm{n}} \mathrm{SiO}_{4}\right]$ and $\left[\mathrm{Q}^{\mathrm{n}}(\mathrm{PO})_{3}\right]$ species [7] [8] [9]. In this regard, the relative ratio of modifier to former is high enough to yield pyrosilicate $\left(\mathrm{Q}^{1}, 3 \mathrm{NBO}\right)$ and orthosilicate $\left(\mathrm{Q}^{0}, 4 \mathrm{NBO}\right)$ units which have been documented from NMR results. The nonbridging oxygen should be electrically balanced by positive ions $\left(\mathrm{Ce}^{2+}\right)$. Accumulation of $\mathrm{Ce}^{2+}$ cations around $\mathrm{NBO}$ in silicate network will result in producing crystalline clusters of cerium orthosilicate type [7] [8] [9]. These considerations are supported from comparison between XRD pattern of vitreous $\mathrm{CeO}_{2}$ and of that of cerium silicate glass. Both spectra offer sharp diffraction lines at the same position. The intensity of the diffraction pattern of cerium silicate glass is appeared to be lower than that of 
the pure $\mathrm{CeO}_{2}$. This may because the clusters formed from $\mathrm{Ce}$ and $\mathrm{O}$ ions are distributed within amorphous silicate units which play the role of lowering the total crystallite species. This argument is further supported, since the sharp diffraction peak is superimposed on a broad hump (between $20^{\circ}-40^{\circ}$ ) which is a characteristic feature of the main amorphous glass network. This observation is simply strengthened from XRD spectra of cerium free glass, Figure 5, since amorphous distribution of glass constituents is the dominant.

Glass contains $\mathrm{SiO}_{2}$ and $\mathrm{PbO}$ doesn't greatly affect the process of crystallization or clustring, but the main changes were found to depend on $\mathrm{CeO}_{2}$. Figure 6 showed that there is a great difference between morphology of glass containing
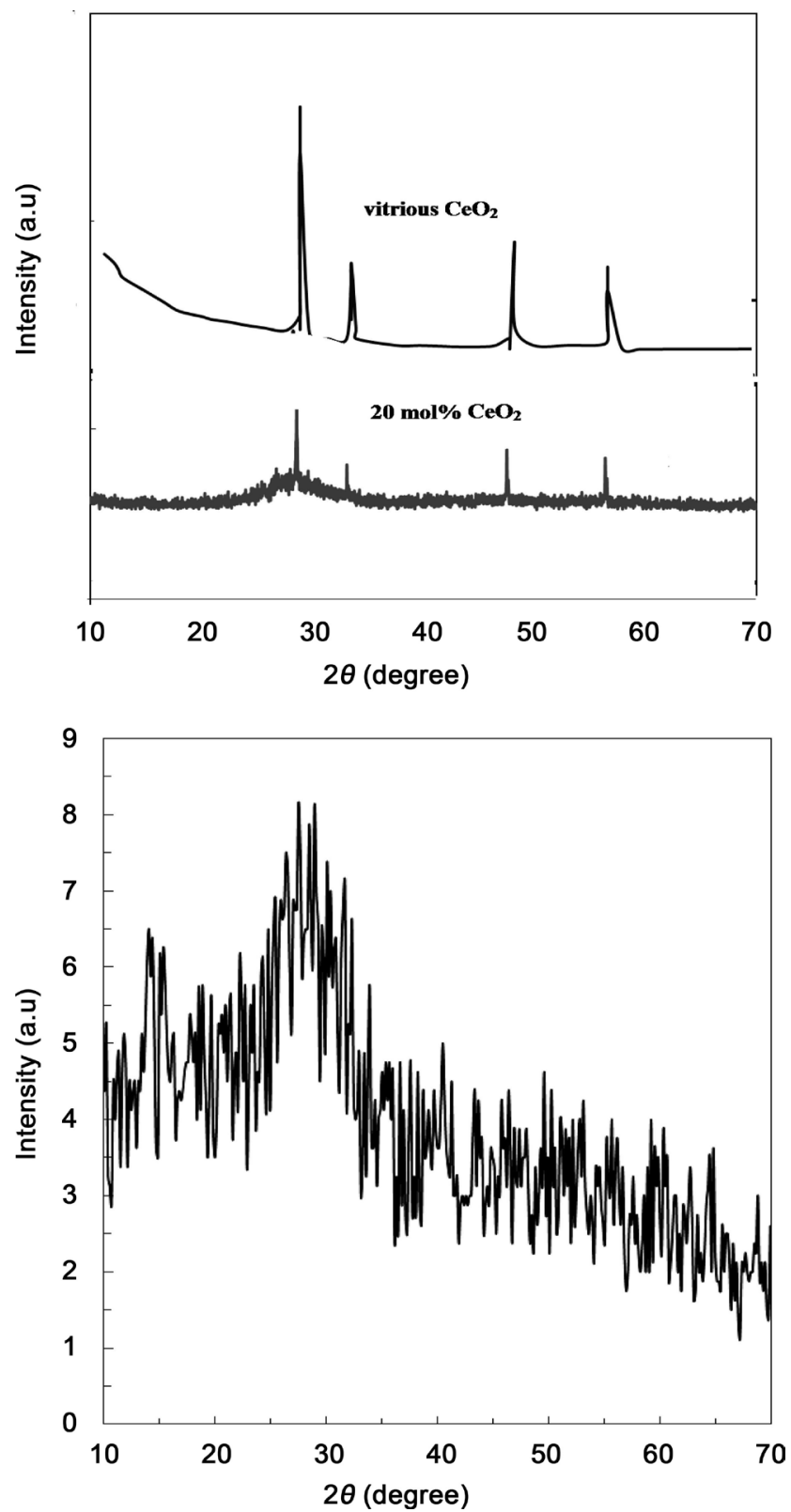

Figure 5. XRD patterns of glass free from $\mathrm{CeO}_{2}$ (below) and that of glass containing 20 mol\% $\mathrm{CeO}_{2}$ together with vitreous $\mathrm{CeO}_{2}$. 


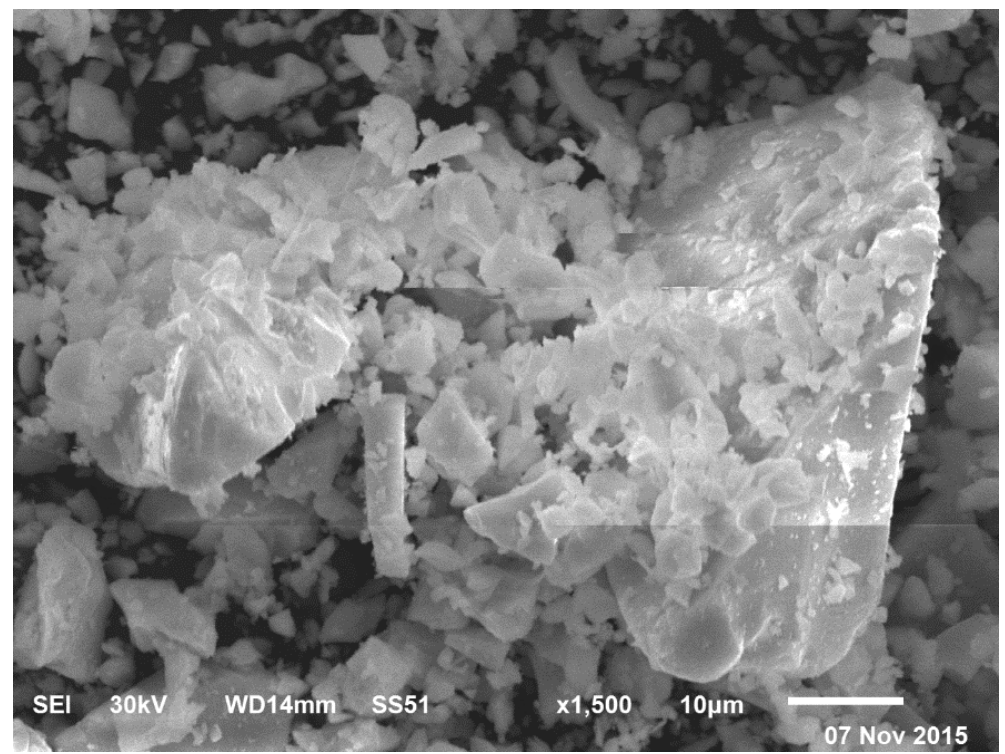

(a)

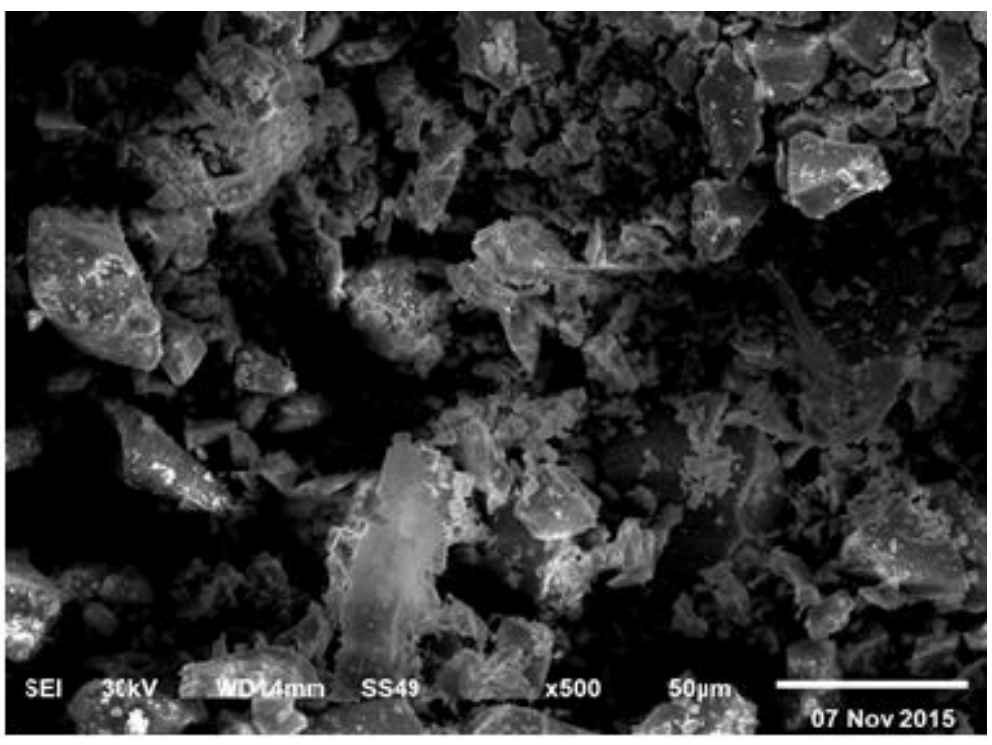

(b)

Figure 6. SEM of glass containing $20 \mathrm{~mol} \% \mathrm{CeO}_{2}$ (a) and of glass free from $\mathrm{CeO}_{2}$ (b).

$20 \mathrm{~mol} \% \mathrm{CeO}_{2}$, Figure 6(a) and of cerium free glass, Figure 6(b), since crystalline clusters from cerium silicate phases are clearly resolved in the morphology of sample containing $20 \mathrm{~mol} \% \mathrm{CeO}_{2}$.

\section{Conclusion}

NMR investigation has revealed that increasing of $\mathrm{CeO}_{2}$ at the expense of $\mathrm{SiO}_{2}$ at a constant concentration of $\mathrm{PbO}$ increases chemical shift $(\delta)$ of ${ }^{29} \mathrm{Si}$ nuclei through increasing (NBO) in silicate network. NBO atoms in cerium free glass are much lower than those of glasses containing $\mathrm{CeO}_{2}$. Higher concentration of $\mathrm{CeO}_{2}$ leads to higher chemical shift and higher NBO. The structural role of $\mathrm{CeO}_{2}$ is definitely determined as a modifier oxide in the investigated lead silicate net- 
work. FTIR analysis revealed that increasing $\mathrm{CeO}_{2}$ will result in increasing silicate units which are enriched with $\mathrm{NBO}$ atoms The major modifiers are consumed to form $\mathrm{NBO}$ in silicate network and the few are aggregated to form crystalline silicate phase riches with cerium oxide. XRD patterns of cerium containing glasses reflect the crystalline order of the glasses which is totally differed from that of cerium free glass, since amorphous character is the dominant.

\section{References}

[1] Akasaka, Y., Yasui, I. and Nanba, T. (1993) Network Structure of $\mathrm{RO}_{2}-2 \mathrm{~B}_{2} \mathrm{O}_{3}$ Glasses. Physics and Chemistry of Glasses, 34, 232-237.

[2] Iwadate, Y., Hattori, T., Nishiyama, S., Fukushima, K., Igawa, N. and Noda, K. (1996) Short-Range Structural Analysis of an Oxide Glass Composed of Light and Heavy Elements: $3 \mathrm{~B}_{2} \mathrm{O}_{3}-2 \mathrm{PbO}$ Glass by X-Ray Diffraction. Journal of Materials Science Letters, 15, 776-780. https://doi.org/10.1007/BF00274601

[3] Takaishi, T., Jin, J., Uchino, T. and Yoko, T. (2000) Structural Study of $\mathrm{PbO}-\mathrm{B}_{2} \mathrm{O}_{3}$ Glasses by X-Ray Diffraction and ${ }^{11} \mathrm{~B}$ MAS NMR Techniques. Journal of the American Ceramic Society, 83, 2543-2548. https://doi.org/10.1111/j.1151-2916.2000.tb01588.x

[4] Fayon, F., Bessada, C., Massiot, D., Farnan, I. and Coutures, J.P. (1998) ${ }^{29} \mathrm{Si}$ and ${ }^{207} \mathrm{PbNMR}$ Study of Local Order in Lead Silicate Glasses. Journal of Non-Crystalline Solids, 232-234, 403-408. https://doi.org/10.1016/S0022-3093(98)00470-0

[5] Imaoka, M., Hasegawa, H. and Yasui, I. (1986) X-ray Diffraction Analysis on the Structure of the Glasses in the System $\mathrm{PbO}-\mathrm{SiO}_{2}$. Journal of Non-Crystalline Solids, 85, 393-412. https://doi.org/10.1016/0022-3093(86)90011-6

[6] El-Damrawi, G. and Gharghar, F. (2017) Magnetic Properties of $\mathrm{xCeO}_{2} \cdot(50-\mathrm{x})$ $\mathrm{PbO} \cdot 50 \mathrm{~B}_{2} \mathrm{O}_{3}$ Glasses and Glass Ceramics. Journal of Advances in Physics, 13, 4486-449.

[7] El-Damrawi, G., Gharghar, F. and Ramadan, R. (2016) Structural Studies on New $\mathrm{xCeO}_{2} \cdot(50-\mathrm{x}) \mathrm{PbO} \cdot 50 \mathrm{~B}_{2} \mathrm{O}_{3}$ Glasses and Glass Ceramics. Journal of Non-Crystalline Solids, 452, 291-296. https://doi.org/10.1016/j.jnoncrysol.2016.09.011

[8] Walkey, C., Das, S., Seal, S., Erlichman, J., Heckman, K., Ghibelli, L., James, E., McGinnis, F. and Self, W.T. (2015) Catalytic Properties and Biomedical Applications of Cerium Oxide Nanoparticles. Environmental Science: Nano, No. 1.

[9] Deliormanli, A.M. (2015) Synthesis and Characterization of Cerium- and Gallium-Containing Borate Bioactive Glass Scaffolds for Bone Tissue Engineering, Journal of Materials Science: Materials in Medicine, 26, 67. https://doi.org/10.1007/s10856-014-5368-0

[10] Salinas, A.J., Shruti, S., Malavasi, G., Menabue, L. and Vallet-Regí, M. (2011) Substitutions of Cerium, Gallium and Zinc in Ordered Mesoporous Bioactive Glasses. Acta Biomaterialia, 7, 3452-3458. https://doi.org/10.1016/j.actbio.2011.05.033

[11] Biochem, C. (2006) Cerium and Yttrium Oxide Nanoparticles Are Neuroprotective. Biochemical and Biophysical Research Communications, 342, 86-91, https://doi.org/10.1016/j.bbrc.2006.01.129

[12] Das, M., Patil, S., Bhargava, N., Kang, J.-F., Riedel, L.M., Seal, S. and Hickman, J.J. (2007) Auto-Catalytic Ceria Nanoparticles Offer Neuroprotection to Adult Rat Spinal Cord Neurons. Biomaterials, 28, 1918-1925. https://doi.org/10.1016/j.biomaterials.2006.11.036 
[13] Kaur, A., Khanna, A., Singla, S., Dixit, A., Kothiyal, G.P., Krishnan, K., Aggarwal, S.K., Sathe, V., González, F. and González-Barriuso, M. (2013) Structure-Property Correlations in Lead Silicate Glasses and Crystalline Phases. Phase Transitions, 86, 759-777. https://doi.org/10.1080/01411594.2012.707655

[14] Furukawa, T., Fox, K.E. and White, W.B. (1981) Raman Spectroscopic Investigation of the Structure of Silicate Glasses. III. Raman Intensities and Structural Units in Sodium Silicate Glasses. The Journal of Chemical Physics, 75, Article ID: 3226e3237. https://doi.org/10.1063/1.442472

[15] Shrikhande, K.V., Sudarsan, V., Kothiyat, P.G. and Kulshreshtha, K.S. (2001) ${ }^{29} \mathrm{Si}$ MAS NMR and Microhardness Studies of Some Lead Silicate Glasses with and without Modifiers. Journal of Non-Crystalline Solids, 283, 18. https://doi.org/10.1016/S0022-3093(01)00486-0

[16] Choi, W.C., Lee, H.N., Kim, E.K., Kim, Y., Park, C.-Y., Kim, H.S. and Lee, J.Y. (1999) Violet/Blue Light-Emitting Cerium Silicates. Applied Physics Letters, 75, 2389-2391. https://doi.org/10.1063/1.125023

[17] Wang, Z. and Cheng, L. (2015) Structural Features and Synthesis of $\mathrm{CeO}_{2}$-Doped Boroaluminosilicate Oxyfluoride Transparent Glass Ceramics. Journal of Chemistry, 2015, 1-10.

[18] Culea, E., Pop, L. and Bosca, M. (2010) Structural and Physical Characteristics of $\mathrm{CeO}_{2}-\mathrm{GeO}_{2}-\mathrm{PbO}$ Glasses and Glass Ceramics. Journal of Alloys and Compound, 505, 754-757. https://doi.org/10.1016/j.jallcom.2010.06.135

[19] El Damrawi, G., Müller-Warmuth, W., Doweidar, H. and Gohar, A. (1992) Structure and Heat Treatment Effects of Sodium Borosilicate Glasses as Studied by ${ }^{29} \mathrm{Si}$ and ${ }^{11}$ B NMR. Journal of Non-Crystalline Solids, 146, 137-144. https://doi.org/10.1016/S0022-3093(05)80485-5

[20] El-Damrawi, G., Müller-Warmuth, W., Doweidar, H. and Gohar, I.A. (1993) ${ }^{29} \mathrm{Si}$ and ${ }^{27} \mathrm{Al}$ Nuclear Magnetic Resonance Studies of $\mathrm{Na}_{2} \mathrm{O}-\mathrm{Al}_{2} \mathrm{O}_{3}-\mathrm{B}_{2} \mathrm{O}_{3}-\mathrm{SiO}_{2}$ Glasses. Physics and Chemistry of Glasses, 34, 52-57.

[21] Eldamrawi, G., Hassan, A.K., Kamal, H., Aboelez, M. and Labeeb, S. (2016) Structural Investigations on $\mathrm{Na}_{2} \mathrm{O}-\mathrm{CaO}-\mathrm{V}_{2} \mathrm{O}_{5}-\mathrm{SiO}_{2}$ Bioglass Ceramics. British Journal of Applied Science \& Technology, 16, 1-9.

[22] El-Damrawi, G., Doweidar, H. and Kamal, H. (2014) Characterization of New Categories of Bioactive Based Tellurite and Silicate Glasses. Silicon, 9, 503-509.

[23] El-Damrawi, G., Doweidar, H. and Kamal, H. (2013) Structure and Crystallization Behavior of Silicate-Based Bioactive Glass Ceramics. Australian Journal of Basic and Applied Sciences, 7, 573-583. 